\title{
ANALISIS SENYAWA BERBAHAYA DALAM PARFUM DENGAN KROMATOGRAFI GAS-SPEKTROMETRI MASSA BERDASARKAN MATERIAL SAFETY DATA SHEET (MSDS)
}

\author{
Filasavita Prasasti Iswara, Dwiarso Rubiyanto dan Tatang Shabur Julianto \\ Jurusan Ilmu Kimia, FMIPA, Universitas Islam Indonesia, Yogyakarta \\ Email: filasavita@ymail.com
}

\begin{abstract}
This study was conducted to determine the harmful compounds in perfumes by gas chromatography-mass spectrometry (GC-MS). Perfume samples (A, B, C) obtained from the supermarket and the refill perfume fragrance that is almost the same. Methodology is the determination of specific gravity and refractive index. Chemical analysis performed using gas chromatography-mass spectrometry (GC-MS). Based on the results obtained three samples of data that have perfume composition profiles of the same constituent that is solvent, fixative agents, and perfuming agents. Compounds that are solvent are methanol, ethanol. Compounds that are fixative agent is 1,2-Butanediol, 3-ethoxy-1-propanol, limonene, dipropylene glycol, 2-(2-hydroxypropoxy)-1-propanol, 3,3'-oxybis-2-butanol. The compound is a substance which is dihydrojasmonat methyl fragrance, alpha-hexyl cinnamaldehyde. Dihydrojasmonat methyl is a compound that becomes the deciding factor perfume that smells like jasmine.
\end{abstract}

Keywords : Perfume, Perfume composition, Jamine, Methyl dihydrojasmonato, Gas chromatographymass spectrometry

\section{PENDAHULUAN}

Parfum adalah produk yang sudah tidak asing lagi dalam kehidupan sehari-hari. Apalagi saat ini aroma parfum yang ditawarkan sudah semakin beragam, baik yang dikhususkan untuk pria, wanita, ataupun untuk keduanya. Kata parfum sendiri berasal dari bahasa latin "per fumum” yang berarti melalui asap. Riwayat parfum telah ada sejak zaman Mesopotamia kuno sekitar lebih dari 4000 tahun yang lalu. Pada zaman dahulu, orang-orang menggunakan tanaman herbal, rempahrempah dan bunga dan dicampurkan bersama untuk membuat wewangian. Selanjutnya pada pertengahan abad ke-15 parfum mulai dicampur minyak dan alkohol. Meskipun demikian, parfum baru mengalami kemajuan pesat pada abad ke-18 dengan munculnya beragam aroma wewangian dan botol yang indah.

Setiap produk wewangian mengandung pelarut tambahan yang berfungsi sebagai media atau fondation baik parfum itu asli atau sintesis. Persentase kandungan bahan kimia dalam parfum antara kisaran 30 \% tergantung dari jenis produknya. Namun dari beberapa analisa pasar, 95 \% bahan kimia yang terkandung di dalam produk wewangian adalah bahan kimia sintetik yang berbahan dasar petroleum yang merupakan turunan benzene, aldehid atau zat yang umumnya terkenal beracun. Salah satu organisasi di Amerika yang menangani masalah 
kesehatan lingkungan menemukan zat kimia beracun dari 815 sampel yang mereka ambil. Tes yang dilakukan pada tahun 1991 menemukan zat-zat yang terkandung adalah kloroform yang dapat juga ditemui pada pelembut pakaian dan $p$-diklorobenzena yang telah diketahui bersifat karsinogenik pada produk penyegar ruangan dengan dosis yang tinggi.

Menurut Cook (2009) ahli gizi holistik dan naturopati sekaligus penulis buku kesehatan popular mengatakan terdapat 500 lebih bahan kimia berbahaya yang menjadi bahan dasar pembuatan wewangian di parfum. Kebanyakan berasal dari bahan kimia sintetis yang diperoleh dari bahan petrokimia, dan telah terbukti mengandung neurotoxin (racun yang bisa merusak pembuluh darah atau syaraf otak). Dan terdapat juga kandungan karsinogenik (bahan yang dianggap sebagai penyebab kanker). Penelitian ini amat mengejutkan, karena hampir semua wanita bahkan pria mengenakan parfum. Siapa sangka banyak bahan kimia yang terkandung dalam parfum atau wewanian lain yang tak kalah berbahaya dibandingkan bahaya asap rokok.

Ada beberapa alasan mengapa konsumen menggunakan parfum. Dari hasil penelitian Borgave \& Chaudari (2010), konsumen merasa lebih baik dan merasa lebih percaya diri setelah menggunakan parfum. Hasil penelitian lainnya dari Borgave \& Chaudari (2010), adalah konsumen menilai wangi parfum berada di urutan pertama yang dipertimbangkan pada saat akan membeli parfum. Urutan selanjutnya adalah merek, harga, dan kemasan parfum itu sendiri.
Parfum diyakini sebagai salah satu indikator untuk meningkatkan kepercayaan diri seseorang. Varian aromanya yang semakin beragam, membuat para wanita gemar untuk menjadikannya sebagai koleksi meja rias.

\section{TUJUAN}

1. Untuk mengetahui senyawa apa yang menjadi faktor penentu yang terdapat dalam sampel parfum yang dianalisis.

2. Untuk mengetahui senyawa yang berbahaya dalam parfum yang dianalisis.

\section{METODE PENELITIAN}

\section{A. Bahan}

Bahan yang digunakan dalam penelitian ini adalah Tiga sampel parfum dan aquades.

\section{B. Peralatan}

Alat yang digunakan dalam penelitian ini adalah gas chromatographyspectrometry massa (GC-MS), thermometer, refraktometer, piknometer, gelas ukur $10 \mathrm{~mL}$, pipet ukur $5 \mathrm{~mL}$, labu ukur 10mL, dan corong.

\section{Prosedur}

\section{Penetapan Berat Jenis}

Penetapan berat jenis dilakukan dengan menggunakan piknometer ukuran 5 $\mathrm{ml}$ dalam keadaan bersih, kering, dan kosong dan ditimbang. Kemudian piknometer diisi dengan aquades $5 \mathrm{ml}$ dan ditimbang. Setelah itu piknometer dibersihkan, dikeringkan, dan ditimbang. Piknometer diisi dengan sampel parfum dan ditimbang.

\section{Penetapan Indeks Bias}


Penetapan indeks bias dilakukan dengan menggunakan refraktometer. Permukaan prisma refraktometer dibersihkan dengan aquades dan tissue. Kemudian diteteskan senyawa cair (sampel) pada permukaan prisma. Setelah itu ditutup dan dibiarkan berkas cahaya memasuki dan melewati senyawa cair. Diatur prisma agar warna cahaya pada layar dalam alat refraktometer tersebut menjadi dua warna dengan batas yang jelas. Setelah itu digeser tanda batasnya dengan menggunakan knop pengatur pada refraktometer sampai memotong titik perpotongan dua garis diagonal yang saling berpotongan. Kemudian diamati dan dibaca skala indeks bias yang terlihat pada refraktometer dan dicatat hasinya. Setelah selesai pengukuran dibuka penutupnya dan dibersihkan permukaan prisma dari sampel sampai bersih.

\section{Analisis Sampel dengan Kromatografi Gas}

Tiga sampel parfum, yaitu sampel A, $\mathrm{B}$, dan $\mathrm{C}$, masing-masing diambil $1 \mathrm{~mL}$ dan dimasukkan ke dalam labu ukur yang berpenutup. Selanjutnya tersebut dianalisis dengan kromatografi gas-spektrometri massa.

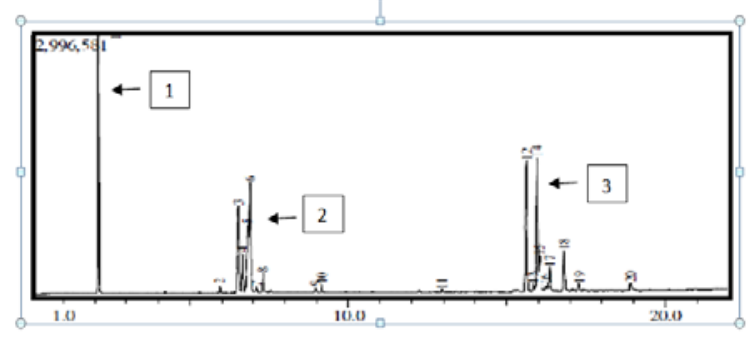

Gambar 3. Contoh kromatogram sampel parfum A. Puncak 1 merupakan zat pelarut, puncak 2 zat pengikat dan puncak 3 zat pewangi. Kondisi oprasional kromatogarfi adalah Fasa Diam: Rtx-5 MS (Crossbond 5\% diphenyl / 95\% dimethyl polysilaxone) ; Dimensi : 30 meter, 0,25 mmID, 0,25 um df ; Max Prog. Temp. $350^{\circ}$; Min. Bleed at $330^{\circ} \mathrm{C}$; Fasa Gerak : Helium

Berdasarkan contoh kromatogram pada gambar 3 dapat dilihat bahwa senyawa yang terikat lebih kuat dengan fasa diam akan tertahan lebih lama didalam kolom, sehingga waktu retensi senyawa lebih panjang. Puncak kromatogram yang ada pada kromatogram kemudian dikelompokkan menjadi tiga kelompok komposisi dalam parfum. Puncak 1 merupakan senyawa pelarut. Senyawa pada puncak 2 merupakan zat pengikat, dan senyawa pada puncak 3 merupakan zat pewangi dari sampel parfum A. Puncakpuncak pada kromatogram di atas memiliki luas area yang dinyatakan dalam persen luas (\% area). Puncak-puncak yang memiliki persen luas antara $1 \%$ sampai dengan $16,75 \%$ selanjutnya dianalisis dengan menggunakan spektrometri massa.

\section{Analisis Sampel dengan Spektrometri Massa}

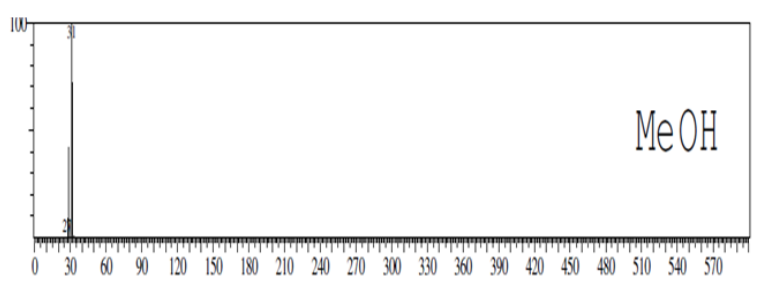

Gambar 4. Contoh fragmentasi massa $(\mathrm{m} / \mathrm{z})$ sampel parfum A dari puncak 1 pada gambar 3. 
Gambar 4 menunjukkan fragmentasi massa (m/z) sampel parfum A dari puncak 1 pada gambar 3. Fragmentasi massa pada gambar 4 dibandingkan dengan nilai SI (similarity index) pada pustaka instrument kromatografi gas-spektrometri massa. Angka SI yang lebih besar dari 95\% dianggap menyerupai fragmentasi puncak 1 pada senyawa A. Sehungga disimpulkan bahwa puncak 1 tersebut adalah methanol. Bila ditemukan nilai SI yang sama dari fragmentasi sebuah puncak maka dipilih fragmentasi senyawa dengan berat molekul terendah sebagai fragmentasi puncak yang dianalisis.

\section{HASIL DAN PEMBAHASAN}

Dalam penelitian ini, selain melakukan analisis secara kimia juga dilakukan analisis secara fisik. Dimana tujuan dari analisis fisik ini untuk mengetahui identitas dari sampel parfum. Analisis fisika meliputi wujud sampel, berat jenis dan indeks bias. Berikut adalah data hasil dari analisis fisika maupun kimia :

Tabel 1. Data Analisis Fisika dan Kimia

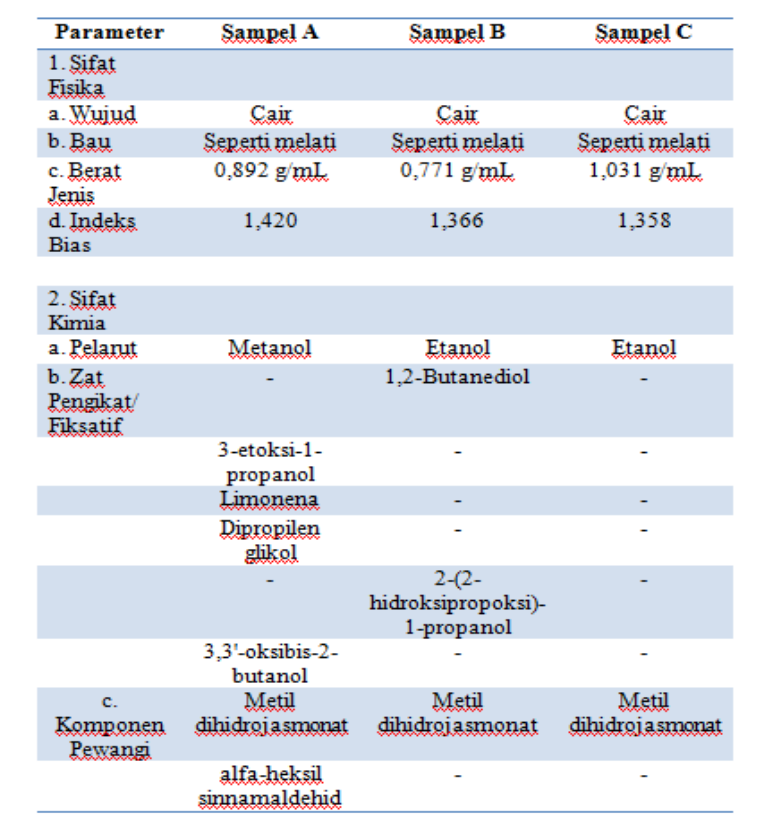

\section{GC-MS}

Identifikasi sampel parfum dengan menggunakan kromatografi gas dilakukan dengan cara sampel parfum diinjeksikan kedalam ruang injeksi yang telah dipanaskan. Sampel kemudian dibawa oleh gas pembawa melalui kolom untuk dipisahkan. Didalam kolom fase diam akan menahan komponen-komponen secara selektif berdasarkan koefisien distribusinya dan akan dialirkan ke detektor yang memberi sinyal untuk kemudian dapat diamati pada sistem pembaca.

Identifikasi sampel parfum dengan menggunakan spektrometri massa dengan data spektra massa standar yang tersimpan dalam kepustakaan instrument kromatografi gas-spektroskopi massa. Perbandingan dilakukan dengan melihat nilai SI atau indeks spektra senyawa yang ada pada komputer. Semakin tinggi nilai SI, maka senyawa itu akan semakin mirip dengan senyawa yang dianalisis. Sehingga dapat ditampilkan bahwa sampel tersebut sama 
dengan senyawa yang memiliki SI tertinggi dalam data komputer yang diberikan komputer. Dengan metode ini, maka alat kromatografi gas-spektrometer massa dapat digunakan untuk menentukan nama senyawa tanpa memerlukan senyawa standar yang digunakan dalam metode spiking pada kromatografi gas (Hapsari, 2008).

Adapun profil kromatogram dari setiap sampel dapat dilihat pada gambar :
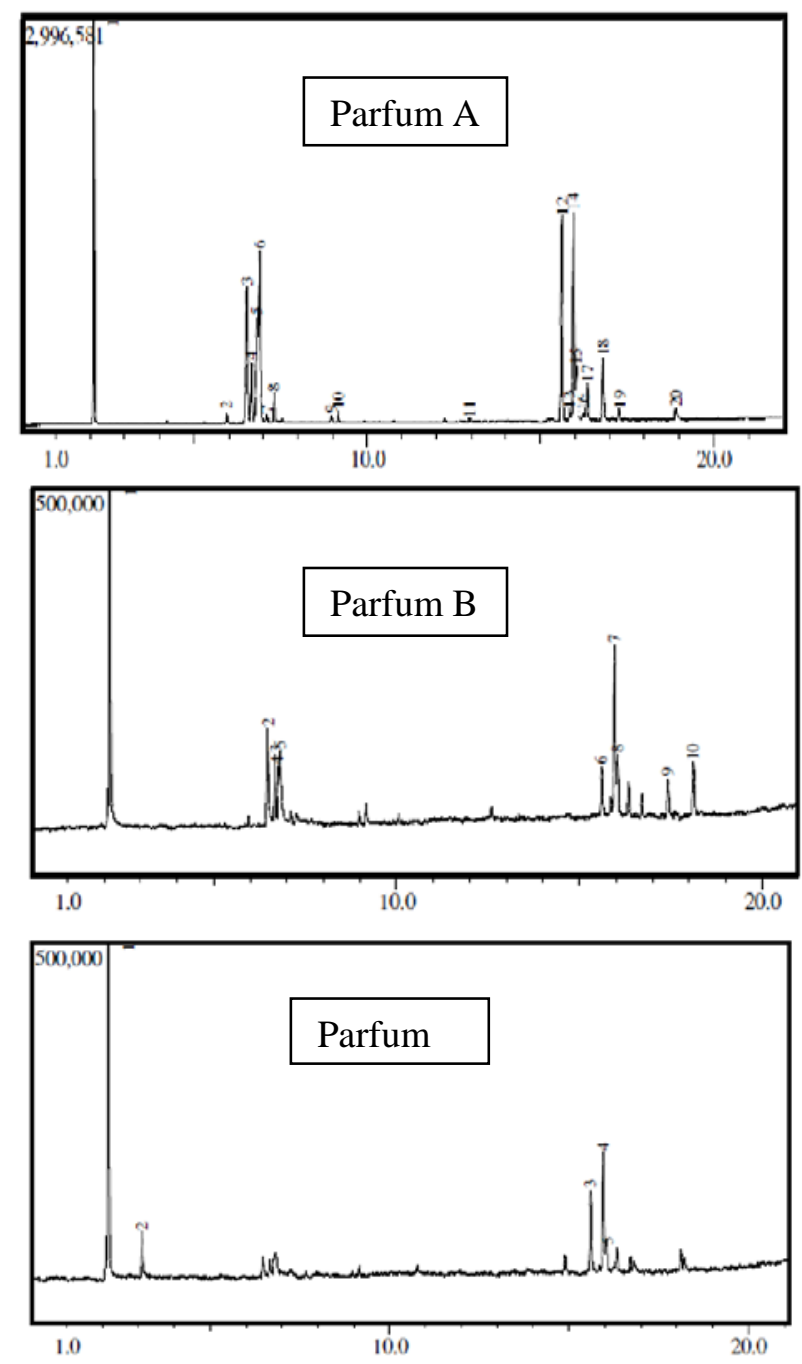

Gambar 1. Hasil Kromatogram Sampel Parfum

Dari data kromatogram di atas dapat diartikan bahwa komposisi parfum dapat kita kelompokkan menjadi tiga. Apabila dihubungkan dengan data hasil spektrometri massanya senyawa tersebut terdiri dari pelarut, zat pengikat, dan zat wangi.

Analisis komposisi kimia dapat diuraikan sebagai berikut :

\section{Pelarut}

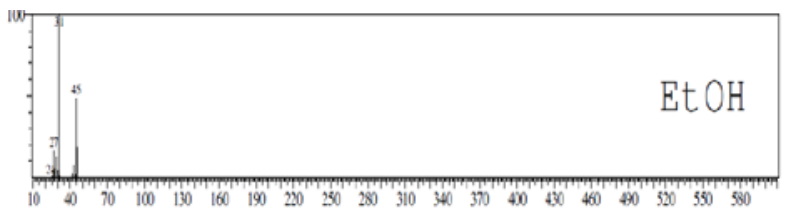

Gambar 2. Hasil Spektrometri Massa Etanol

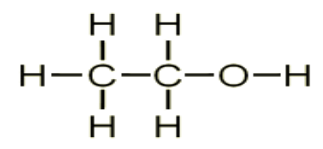

Gambar 3. Struktur Etanol

Berdasarkan material safety data sheet (MSDS) etanol adalah senyawa yang mudah terbakar, jika terjadi kontak langsung dengan mata dapat menyebabkan iritasi, mata kemerahan, nyeri, kornea, peradangan, dan kerusakan kornea. Selain itu, bahaya untuk kulit jika dalam waktu pendek maupun panjang dapat menyebabkan kulit kemerahan, gatal, peradangan. Bahkan jika digunakan berulang-ulang dapat menyebabkan reaksi alergi kulit pada sebagian kecil individu atau manusia. Berkaitan dengan karsinogen atau bahan yang dianggap sebagai penyebab kanker, mengkonsumsi alkohol dalam jangka panjang dapat menyebabkan terjadinya kanker, tumor ganas rongga mulut, faring, laring, esophagus dan hati. Berikut adalah batas paparan dari etanol :

Tabel 2. Batas Paparan Etanol

Departemen/Lembaga Batas Paparan

US (OSHA) $1900 \mathrm{mg} / \mathrm{m}^{3}$

US (ACGIH) $1900 \mathrm{mg} / \mathrm{m}^{3}$ 


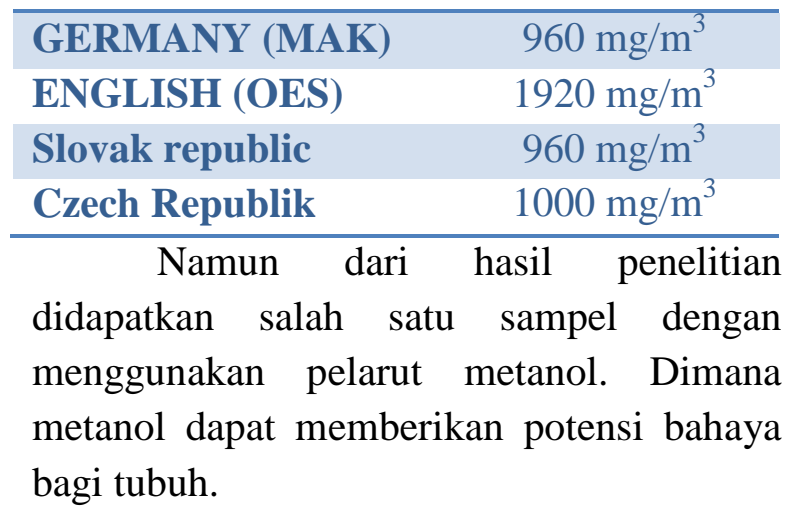

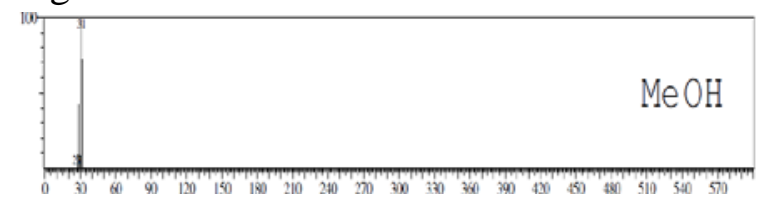

Gambar 4. Hasil Spektrometri Massa Metanol

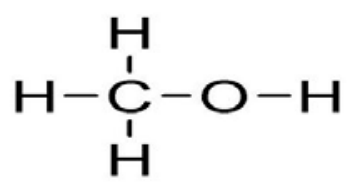

Gambar 5. Struktur Metanol

Berdasarkan material safety data sheet (MSDS) menunjukkan bahwa metanol dapat menyebabkan iritasi kulit, mata, dan iritasi saluran pernafasan. Dapat menyebabkan kerusakan pada sistem saraf pusat. Disamping bahaya iritasi, jika terhirup juga dapat menyebabkan iritasi selaput lendir, sakit kepala, mengantuk, mual, kebingungan, kehilangan kesadaran, gangguan pencernaan dan bahkan kematian. Penggunaan yang berulang-ulang dapat menyebabkan keracunan sistematik, gangguan otak, gangguan penglihatan dan kebutaan. Bahaya untuk kulit jika terjadi kontak secara langsung dapat menyebabkan toksik pada kulit. Penyerapan kulit dapat menyebabkan efek toksik dan jika digunakan secara berulang-ulang atau berkepanjangan dapat menyebabkan eritema (kemerahan pada kulit) atau dermatitis. Jika terhirup dapat menyebabkan kebutaan, uapnya dapat menyebabkan mengantuk atau pening. Untuk efek yang tertunda jika digunakan secara terus-menerus dapat menyebabkan kerusakan pada hati dan system saraf pusat. Metanol dapat menghasilkan kerusakan saraf optik, saraf pusat, dan saraf motorik. Berikut adalah batas paparan dari metanol :

Tabel 3. Batas Paparan Metanol

\begin{tabular}{lc}
\hline \multicolumn{1}{c}{ Departemen/Lembaga } & $\begin{array}{c}\text { Batas } \\
\text { Paparan }\end{array}$ \\
\hline US (ACGIH) & 200ppm TWA \\
\hline US (OSHA) & 250ppm STEL \\
\hline ENGLISH (NIOSH) & 200ppm TWA \\
& 250ppm STEL \\
\hline
\end{tabular}

\section{Zat Pengikat (Fiksatif)}

Zat pengikat adalah suatu zat alami atau sintetis yang digunakan untuk mengurangi tingkat penguapan dan meningkatkan stabilitas ketika ditambahkan ke komponen volatil, dengan tujuan memungkinkan produk akhir untuk bertahan lebih lama dengan menjaga aroma aslinya. Berdasarkan tabel data diatas diperoleh beberapa senyawa yang menjadi zat pengikat parfum. Diantaranya 1,2butanediol, 3-etoksi-1-propanol, limonene, dipropilen glikol, 2-(2-hidroksipropoksi)-1propanol, 3,3'-oksibis-2-butanol. Selain itu dari data material safety data sheet (MSDS) juga menyebutkan bahwa dari masingmasing senyawa tersebut dapat memberikan efek negatif meskipun tidak terlalu berbahaya. Berikut adalah data hasil kromatogram dari masing-masing senyawa: 


\section{a) 1,2-Butanediol}

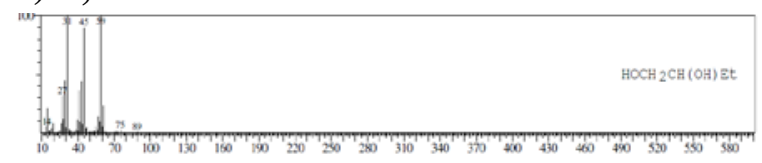

Gambar 6. Hasil Spektrometri Massa 1,2Butanediol<smiles>CCC(O)CO</smiles>

Gambar 7. Struktur 1,2-Butanediol

Senyawa 1,2-butanediol memiliki rumus molekul $\mathrm{C}_{4} \mathrm{H}_{10} \mathrm{O}_{2}$ dengan berat molekul 90 gram/mol. Berdasarkan material safety data sheet (MSDS) senyawa ini dapat memberikan potensi bahaya seperti iritasi mata, dapat menyebabkan cedera kornea, dapat menyebabkan iritasi kulit. Jika dikonsumsi dapat menyebabkan iritasi pada saluran pencernaan, dapat menyebabkan kerusakan ginjal, dan dapat menyebabkan depresi sistem saraf pusat. Selain itu, bahaya jika terhirup dapat menyebabkan iritasi pada saluran pernafasan, dan efek yang sama dengan bahaya jika dikonsumsi. Bahkan efek yang kronis dapat menyebabkan cedera pada ginjal.

\section{b) 3-etoksi-1-propanol}

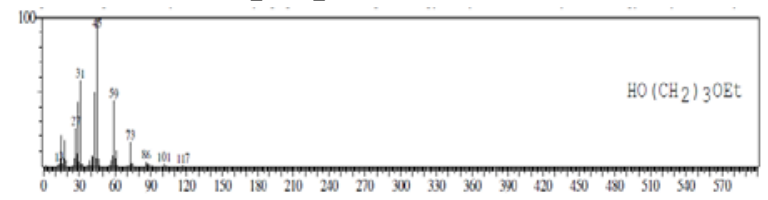

Gambar 8. Hasil Spektrometri Massa 3etoksi-1-propanol<smiles>CCOCCCO</smiles>

Gambar 9. Struktur 3-etoksi-1-propanol

Senyawa ini memiliki rumus molekulC ${ }_{5} \mathrm{H}_{12} \mathrm{O}_{2}$ dengan berat molekul 104 gram/mol. Berdasarkan material safety data sheet (MSDS) memiliki potensi berbayahaya. Dapat menyebabkan iritasi pada kulit, dan jika berulang dapat menyebabkan dermatitis yang ditandai dengan kemerahan, pembengkakan. Dapat juga masuk ke aliran darah melalui kulit yang luka atau lecet. Menyebabkan iritasi pada mata. Jika tertelan akan menyebabkan kerusakan pada hati dan ginjal, gangguan saluran pencernaan. Selain itu jika terhirup akan menyebabkan gangguan pada saluran pernafasan.

\section{c) Limonena}
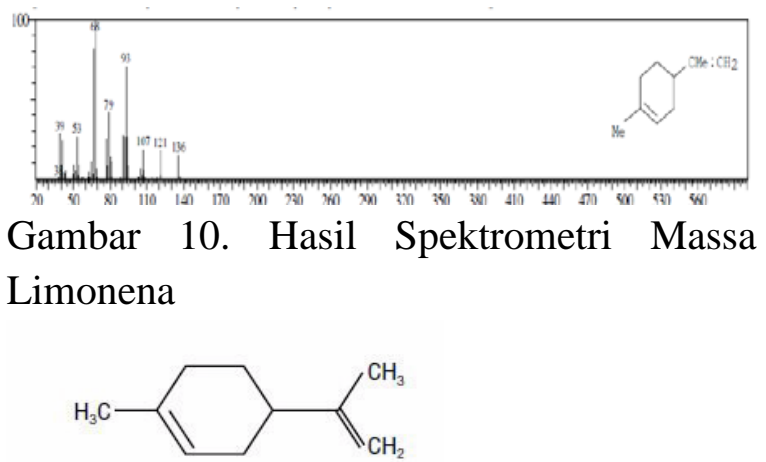

Gambar 11. Struktur Limonena

Limonena mengambil namanya dari sari lemon. Sebagai kulit lemon, seperti buah jeruk lainnya mengandung sejumlah senyawa yang memberikan kontribusi untuk bau mereka. Limonena memiliki berat jenis $0,84 \mathrm{~g} / \mathrm{cm}^{3}$. Hal ini digunakan untuk wewangian, dan dalam dunia kesehatan manfaatnya sangat luas termasuk sebagai kemoprevensi kanker.

Dalam material safety data sheet (MSDS) limonena mempunyai potensi yang berbahaya seperti iritasi mata, iritasi kulit. Radang mata ditandai dengan mata kemerahan, berair, dan gatal-gatal. Peradangan kulit ditandai dengan gatalgatal, dan kulit kemerahan.

\section{d) Dipropilen Glikol}




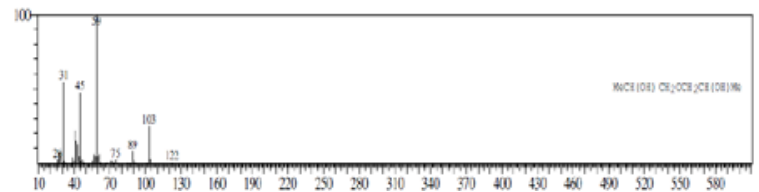

Gambar 12. Hasil Spektrometri Massa dipropilen Glikol<smiles>CC(O)COCC(C)O</smiles>

Gambar 13. Struktur Dipropilen Glikol Dipropilen glikol merupakan senyawa yang memiliki rumus molekul $\left(\mathrm{CH}_{3} \mathrm{CHOHCH}_{2}\right)_{2} \mathrm{O}$ berwujud cairan kental, sedikit larut dalam air dengan titik didih $233^{\circ} \mathrm{C}$, larut dalam toluene dan dalam air. Fungsi dipropilen glikol dalam parfum adalah sebagai zat fiksatif. Zat fiksatif berfungsi sebagai perekat atau pengawet aroma. Zat fiksatif juga berfungsi sebagai penetral cairan kimia karena di dalam fiksatif terdapat sedikit $\mathrm{pH}$ yang berfungsi atau ber-efek tidak menimbulkan iritasi pada kulit namun pada batas paparan tertentu.

Berdasarkan data material safety data sheet (MSDS) Dipropilen glikol dapat menyebabkan iritasi mata ringan sementara, kontak yang terlalu lama tidak akan menyebabkan iritasi kulit yang signifikan. Potensi efek kesehatan yang lain adalah sedikit berbahaya jika terjadi kontak kulit, kontak mata, dan tertelan. Berikut adalah batas paparan dari dipropilen glikol :

Sifat toksik yang rendah membuat dipropilen glikol menjadi zat aditif yang ideal untuk parfum dan produk perawatan kulit dan rambut.

\section{e) 2-(2-Hidroksipropoksi)-1-propanol}

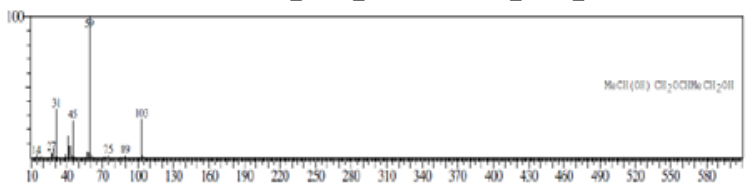

Gambar 14.Hasil Spektrometri Massa 2(2-hidroksipropoksi)-1-propanol<smiles>CC(O)COC(C)CO</smiles>

Gambar 15. Struktur 2-(2-hidroksipropoksi)1-propanol

Senyawa ini mempunyai rumus molekul $\mathrm{C}_{6} \mathrm{H}_{14} \mathrm{O}_{3}$. Senyawa ini memiliki sifat tidak berwarna, tidak berbau, dan toksisitas rendah. Berdasarkan material safety data sheet (MSDS) menyebutkan bahwa ada gambaran darurat dari senyawa ini. Cairan dan uap yang mudah terbakar dapat menyebabkan kerusakan organ seperti mata dan kulit. Hindari kontak langsung dengan kulit dan pakaian. Dan digunakan dalam keadaan ruangan dengan ventilasi yang memadai. Berikut adalah batas paparan dari senyawa 2-(2-Hidroksipropoksi)-1propanol :

Tabel 4. Batas Paparan 2-(2hidroksipropoksi)-1-propanol

\begin{tabular}{|c|c|}
\hline Kota & Batas Paparan \\
\hline \multirow[t]{2}{*}{$\begin{array}{l}\text { SUVA (Switzerland, } \\
1 / 2009)\end{array}$} & $400 \mathrm{mg} / \mathrm{m}^{3} \mathrm{STEL}$ \\
\hline & 200 mg/m³ TWA \\
\hline \multirow[t]{2}{*}{$\begin{array}{l}\text { MAK-Were Liste } \\
\text { (Germany, 7/2009) }\end{array}$} & $400 \mathrm{mg} / \mathrm{m}^{3} \mathrm{PEAK}$ \\
\hline & 200 mg/m³ TWA \\
\hline \multirow[t]{2}{*}{$\begin{array}{l}\text { TRG S900 AGW } \\
\text { (Germany, 7/2009) }\end{array}$} & $67 \mathrm{mg} / \mathrm{m}^{3}$ TWA \\
\hline & $536 \mathrm{mg} / \mathrm{m}^{3} \mathrm{PEAK}$ \\
\hline
\end{tabular}

\section{f) 3,3'-oksibis-2-Butanol}

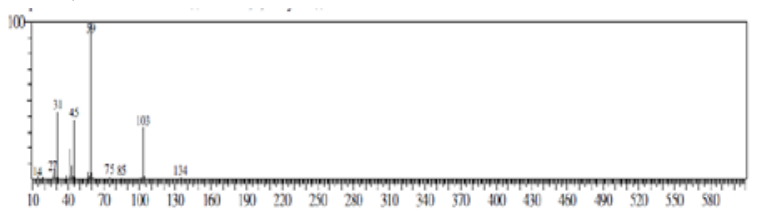


Gambar 16. Hasil Spektrometri Massa 3,3’oksibis-2-butanol<smiles>CC(O)C(C)OC(C)C(C)C(C)O</smiles>

Gambar 17. Struktur 3,3'-oksibis-2-butanol

Senyawa ini menurut literatur Alla dkk (2002) adalah senyawa feromon yang terdapat pada belalang daun. Ini menunjukkan bahwa dalam sampel parfum tidak boleh digunakan karena merupakan feromon serangga.

\section{Zat Pewangi}

Zat pewangi dalam parfum merupakan komponen yang sangat penting. Tidak hanya dalam parfum, hampir setiap produk memiliki komponen pewangi. Mulai dari produk rumah tangga seperti sabun, shampoo, pengharum ruangan. Bahkan pada produk-produk yang tidak harus menggunakan pewangi seperti tissue. Hampir semua orang menyukai produk yang memiliki bau wangi karena terkesan bersih, segar, dan menyenangkan jika menghirupnya. Namun dibalik keuntungannya pada pewangi terdapat bahan kimia yang menjadi dasar pembuatan wewangian yang bisa meracuni tubuh.

Berdasarkan tabel komposisi kimia diatas diperoleh komponen zat pewangi dari ketiga parfum adalah metal dihidrojasmonat.

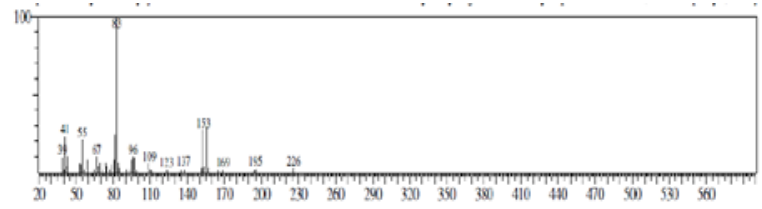

Gambar 18. Hasil Spektrometri Massa Metil Dihidrojasmonat

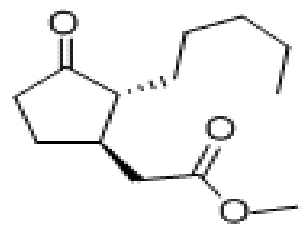

Gambar 19. Struktur Metil Dihidrojasmonat

Metil dihidro jasmonat adalah ester dan senyawa aroma difusi dengan bau samar-samar mirip dengan melati. Senyawa ini digunakan sebagai zat pewangi dalam parfum. Dalam material safety data sheet (MSDS) metal dihidrojasmonat tidak berbahaya bagi kesehatan tubuh. Sehingga masih baik digunakan sebagai zat pewangi dalam parfum.

Dalam penelitian ini senyawa metil dihidrojasmonat merupakan senyawa pokok dari komponen zat pewangi pada ketiga sampel parfum tersebut. Namun selain senyawa metal dihidrojasmonat terdapat juga senyawa alfa-heksil sinnamaldehid.

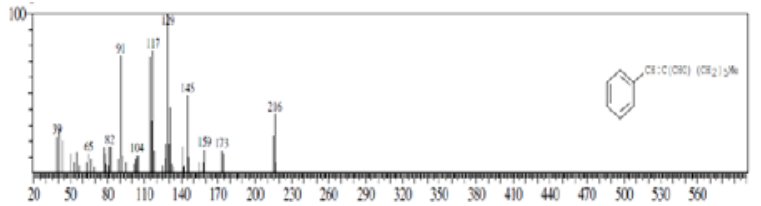

Gambar 20. Hasil Spektrometri Massa alfaheksil sinnamaldehid

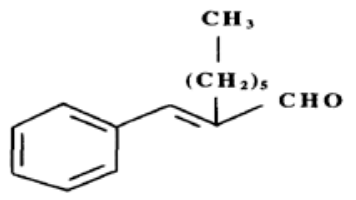

Gambar 21. Struktur alfa-heksil sinnamaldehid

Berdasarkan material safety data sheet (MSDS) jika senyawa ini tertelan akan menyebabkan aspirasi ke dalam paru-paru dengan risiko pneumonitis kimia, dan konsekuensi serius bisa terjadi. Ada beberapa bukti yang menunjukkan bahwa senyawa ini dapat menyebabkan iritasi mata dan kerusakan pada beberapa orang. Jika terjadi kontak kulit tidak memiliki efek kesehatan yang merugikan, 
namun dapat menyebabkan luka seperti lecet, terkelupas, atau kulit yang iritasi tidak boleh terkena senyawa ini. Bahaya jika menghirup uap ini dapat menyebabkan mengantuk atau pening, dapat disertai dengan kehilangan refleksi, kurangnya koordinasi, dan vertigo. Ada beberapa bukti yang menunjukkan bahwa senyawa ini dapat menyebabkan iritasi pernafasan pada beberapa orang. Respon tubuh terhadap iritasi tersebut dapat menyebabkan kerusakan paru-paru lebih lanjut.

\section{KESIMPULAN}

1. Dari ketiga sampel parfum yang dianalisis menunjukkan adanya senyawa yang menjadi faktor penentu aroma parfum tersebut. Senyawa tersebut adalah metal dihidrojasmonat
2. Berdasarkan material safety data sheet (MSDS) dari masing-masing senyawa menunjukkan bahwa hampir semua senyawa dalam parfum mempunyai potensi bahaya bagi penggunanya jika melebihi batas paparan.

\section{UCAPAN TERIMAKASIH}

Penulis mengucapkan terimakasih kepada bapak Dwiarso Rubiyanto S.Si., M.Si dan bapak Tatang Shabur Julianto, S.Si., M.Si yang telah memberikan arahan untuk penelitian ini.

\section{DAFTAR PUSTAKA}

Alla. S, Malosse. C, Cassel. S, Rollia. F, Frerot. B., 2002, Mevalonolactone a Volatile Compound Product, C. R Biol, 325 (9):941-6

Borgave, S. \& Chaudari, J.S., 2010, Adolescents’ Preferences and Attitudes towards Perfumes in India.Journal of Policy and Organizational Management ISSN: 0976-7738 \& E-ISSN: 0976-7746, Vol. 1, Issue 2, 2010, PP-01-08.

Cook, S.M., 1999, The 4-Week Ultimate Body Detox, Canada

Hapsari, S.P., 2008, Isolasi dan Analisis Komponen Penyusun Minyak Kemangi (Ocimum Citriodorum) dengan Kromatografi Gas-Spektrometri Massa, Skripsi, Fakultas Matematika dan Ilmu Pengetahuan Alam, Universitas Islam Indonesia, Yogyakarta. 